\title{
The Effect Of The Number Of Coffee Purchases On The Income Of Drying Workers In Cv. Oro Coffee Gayo In Central Ace District
}

\author{
Eliyin $^{1^{*}}$, Ilma Fitri ${ }^{2}$, Mahyudin Ariga ${ }^{3}$ \\ ${ }^{1,2,3}$ Agribusiness Study Program, Faculty of Agriculture University Gajah Putih \\ ${ }^{*}$ Corresponding Author: \\ Email: eliyinugp@gmail.com
}

\begin{abstract}
.
This research was conducted at CV. Oro Kopi Gayo, Central Aceh Regency, this research was conducted in February 2016. The location determination was determined intentionally by considering that CV. Oro Kopi Gayo is one of the industrial companies engaged in coffee processing and coffee export. The data analysis method used simple linear regression analysis. Based on the results of the partial analysis, the value of tcount $=5.121>$ ttable $=2.228$ with a significant value obtained 0.000 or $<0.05(5 \%)$ then $\mathrm{HO}$ is rejected and Hadi accepts. This shows that the independent variable (number of random purchases) has a partially significant effect on the dependent variable (drying labor acceptance). The average number of random purchases of coffee is 289,552 Kg|Year with the average number of drying workers receiving Rp.33,684,0984, From the results of this study indicate that the higher the number of random coffee purchases, the higher the labor acceptance. drying. So that it can be concluded that the proposed simple linear regression equation model $Y=q+b X$ is acceptable.
\end{abstract}

Keywords: Number of Random Coffee Purchases, Acceptance

\section{INTRODUCTION}

Arabica coffee production in Central Aceh Regency in 2015 was 25,927 Tons/year with an area of 48,300 $\mathrm{Ha}$ and Arabica coffee productivity was $720 \mathrm{Kg} / \mathrm{Ha} / \mathrm{Year}$ with 35,410 families of farmers.Cv Oro Kopi Gayo is a company engaged in the sale and purchase of coffee, usually coffee purchased by $\mathrm{Cv}$. Orokopi Gayo is in the form of random green coffee beans which are then included in the green been process which is ready for export. Green coffee beans usually still have a relatively high water content and are still mixed with pesel, bogor and sesame coffee or coffee that is included in the trace category. The coffee beans purchased by $\mathrm{Cv}$. Oro Kopi Gayo is coffee beans from fostered farmers and conventional (general) coffee beans, usually coffee sourced from fostered farmers are those that have registered certification, while conventional coffee is sourced from general coffee purchases without certain certifications.In the random purchase of green coffee made by $\mathrm{Cv}$. Oro Gayo coffee is usually the peak of buying original green coffee, which is in January to April because this boast is the month of the first coffee harvest in a harvest year, because the coffee harvest in a year is usually twice the harvest period, then purchases will increase again, namely in the month of November to December which is the second harvest period. With the harvest period, the number of purchases made by $\mathrm{Cv}$. Oro Kopi gayo from farmers through collectors will increase.

$\mathrm{CV}$. Oro Kopi Gayo usually buys green coffee beans at random by setting a moisture content of $15 \%$ and Trase $15 \%$ of $100 \mathrm{rg}$ samples of random green coffee beans as a basic reference or usually called the base price. If random coffee beans enter the moisture content of natural coffee beans greater than $15 \%$, it is necessary to dry them until they reach a moisture content of $14 \%$. The drying process is carried out with a wholesale system, so no matter how many random coffee beans are dried in the sun, there will be more and more scales of dried coffee beans. distributed to each drying worker.Based on the above background, the identification of the problem in this study is "Does the Number of Random Coffee Purchases Affect the Acceptance of Drying Workers in CV. Gayo Coffee Oro." Based on the identification of the problem above, the purpose of this study is "To determine the effect of the amount of random coffee purchases on the acceptance of drying workers in CV. Gayo Coffee Oro." This research can be useful for researchers in deepening knowledge in the field of agriculture (agribusiness), especially in the field of coffee bean processing. For companies or actors in agribusiness activities, it can be used as input and consideration in making decisions. As a reference for further research regarding the study of the income of coffee drying workers. 


\section{LITERATURE REVIEW}

\section{Coffee Processing}

Good quality coffee can only be obtained from ripe fruit and through proper processing. Freshly harvested coffee cherries must be processed immediately. The reason is, coffee cherries are easily damaged and cause changes in the taste of brewing coffee. Processing of coffee cherries can be divided into two, namely dry processing or formerly called OIB (Oost Indische Bereiding).

\section{Dry Method Processing}

The dry method processing steps are relatively short and simple. Therefore, processing is usually carried out if the amount of coffee harvested is still limited or there are no adequate tools. This method is often carried out by small farmers or in relatively scattered plantation locations (not in one area). Apart from small farmers, relatively large coffee plantations sometimes do this when the amount of harvest is relatively small.Fresh coffee cherries are generally called wet logs. This coffee fruit has not been processed mechanically and is still protected from the fruit skin. The moisture content of wet-picked logs is about 60$70 \%$. Coffee cherries are processed into coffee beans that are ready to be sold or can be called rice coffee. This coffee bean has been separated from the fruit flesh, fruit skin, horn skin, and epidermis. The water content of ready-to-sell coffee beans is generally $13 \%$.

In general, the order of the dry processing of coffee cherries is as follows.

- Fruit picking.

- Receipt at the factory or warehouse.

- Fruit sorting.

- Fruit drying.

- Peeling the skin of the fruit (pulping).

- Seed drying

- Stripping the skin of the horn (huling).

- Final drying.

- Sorting seeds (grading).

- Packaging.

- Storage

- Distribution or marketing

Wet Method Process

Wet method processing is only used for coffee cherries that are fully ripe or red to blackish in color. Wet processing can produce uniformity and good coffee quality. However, if the processing is not appropriate, there is a risk of damaging the taste of the coffee to become fermented or stinky (Ir. Edy Panggabean. 2011).In the past, coffee processing was only done by the dry method. Over time, with the increasing number of coffee production, unfavorable weather, and high yields, dry processing is considered inefficient for large plantations. Because of this, large plantations process coffee yields using the wet method.

The difference between the wet and dry methods is the process of removing the mucus layer. For the wet method, after the pulping process, there is a fermentation treatment. The process of removing the mucus layer is a bit difficult. Because the pulp has a layer that contains sugar compounds. This mucus layer is an excellent growing medium for the development of microorganisms, such as fungi. This layer has hygroscopic properties so that it can prevent the drying process of seeds and dirt.In Indonesia, the price of coffee that is processed by the wet method is more expensive than the price of coffee that is processed by the dry method. This is the case for the robusta coffee market, especially on the island of Java. Because of this, small farmers have started using wet processing, both for Arabica and Robusta coffee. The following is a complete step-by-step wet method of coffee processing.

- Fruit picking.

- Receipt at the factory or warehouse.

- Fruit sorting.

- Peeling the skin of the fruit (pulping). 
- Fermentation

- Washing

- Drying

- Cooling (tempering).

- Stripping the skin of the horns

- Final drying.

- Sorting seeds (grading).

- Packaging.

- Storage

- Distribution or marketing (Ir. Edy Panggabean. 2011).

Drying aims to reduce the water content of HS coffee beans from about $60 \%$ to a maximum of $12.5 \%$ so that HS coffee beans are relatively safe to be packaged in sacks and stored in warehouses in tropical environmental conditions. Drying can be done in several ways, namely:

Drying Drying is the easiest and cheapest way to dry coffee beans. Drying can be done on a parapara or drying floor. The profile of the drying floor is tilted approximately $5-7$ o 16 with a meeting angle in the middle of the floor. The thickness of the HS coffee bean bed in drying should be $6-10 \mathrm{~cm}$. Turning is done every hour while the coffee is still wet. In the highlands, drying for 2-3 days the moisture content of the seeds only reaches $25-27 \%$, for that it is recommended that further mechanical drying be carried out to reach a moisture content of $12.5 \%$.Mechanical Drying Mechanical drying can be done if the weather does not allow for drying. Drying in this way should be done in groups because it requires a large amount of equipment and investment and a trained operator. By operating the mechanical dryer continuously day and night at a temperature of $45-500 \mathrm{C}$, it takes 48 hours to reach a moisture content of $12.5 \%$. The use of high temperatures above $600 \mathrm{C}$ for drying Arabica coffee should be avoided because it can damage the taste. As for robusta coffee, it usually starts with a higher temperature, which is $90-1000 \mathrm{C}$ with a time of $20-24$ hours to reach a maximum water content of $12.5 \%$. (Directorate of Postharvest Handling, Directorate General of Processing and Marketing of Agricultural Products, Ministry of Agriculture. 2006).

Definition and Concept of Labor

Workforce Understanding the workforce is part of the workforce that is actually involved, or trying to be involved, in production activities, namely the production of goods and services (Mulyadi S, 2003).

Labor. Labor (man power) is a product that has been or is currently working. Or are looking for work, and who are doing other work. Like school, housewife. Practically, the workforce consists of two things, namely the labor force and non-labor force:

a. The labor force consists of the working group and the unemployed or looking for work.

b. Groups that are not in the labor force consist of those who attend school, those who take care of the household, and other groups or receive income from other parties, such as retirees and so on. (A. Hamzah, 1990)

\section{Labor (Labour)}

The term laborer is very popular in the world of labor/employment, besides this term has been used for a long time even starting from the Dutch era also because of the old legislation (before Law no. 13 of 2003 concerning Manpower) uses the term labor. During the Dutch colonial era, what was meant by labor was unskilled workers such as coolies, handymen, foremen who did menial work, these people he called "Bule Callar". Meanwhile, those who work in government and private offices are referred to as "Employees/Employees" (White Collar). The differences that have consequences for the differences in treatment and rights by the Dutch government cannot be separated from the efforts to divide the indigenous people (Then Husni, 2008).

\section{Permanent Labor}

Permanent employees are workers who have a work agreement with an entrepreneur for an indefinite period (permanent). Permanent employees, according to PMK-252, are added as follows: Permanent employees are employees who receive or earn a certain amount of income on a regular basis, including members of the board of commissioners and members of the supervisory board who regularly and 
continuously participate in managing the company's activities directly, as well as employees who works on a contract basis for a certain period of time as long as the employee concerned works full time in the job. (Dumairy.1997)

\section{Freelance Worker}

Temporary employees/casual workers are employees who only receive income if the employee concerned works, based on the number of days worked, the number of units of work produced or the completion of a type of work requested by the employer. What is obtained or the right of freelance workers is to get a salary according to their work or the time they work, without receiving social security. Because the Manpower is contractual, after the contract is completed, the relationship between the worker and the employer is also completed. (Dumairy.1997)

Types of Non-Permanent Employee Income

Income of non-permanent employees or casual workers, in the form of daily wages, weekly wages, unit wages, piece rates or wages paid on a monthly basis;

- Daily wages are wages or benefits received or obtained by employees who are owed or paid daily.

- Weekly wages are wages or benefits received or obtained by employees who are owed or paid weekly.

- Unit wages are wages or benefits received or obtained by employees who are owed or paid based on the number of units of work produced.

Piece rate wages are wages or benefits received or obtained by employees who are owed or paid based on the completion of a certain type of work. According to Rivai (2004).

\section{Wholesale Labor}

Bulk or pecokan is an employment relationship based on freelance piecework with the distribution of results according to wages for units of work or wages received based on the goods that can be completed. (Dumairy.1997)

Admission

Revenue in economics is defined as a result in the form of money or other material things achieved from the use of wealth or human services, a person's condition can be measured using the concept of income which shows the total amount of money received by a person or household during a certain period of time. (Samuelson: 2002).

\section{METHODS}

\section{Simple Linear Regression Analysis}

\section{Simple Linear Regression}

Simple linear regression is linear regression that only involves two variables (variables $\mathrm{X}$ and $\mathrm{Y}$ ), the regression line equation can be written in two forms, namely as follows. M Iqbal Hasan (2002)

$\mathrm{Y}=+\mathrm{Bx} 1$

Where :

$\mathrm{Y}:$ dependent variable

$\mathrm{X}$ : Independent variable

Intercept

$\mathrm{b}:$ Regression coefficient

\section{Conformity Test on Multiple Linear Regression}

\section{Simultaneous Coefficient Testing (F Test)}

To test the regression coefficient simultaneously or towards the linearity of the multiple linear regression equation, the $\mathrm{F}$ test is used, with the following steps:

Hypothesis Formula

$\mathrm{H} 0: \mathrm{b} 1=\mathrm{b} 2=\mathrm{b} 3=0\llcorner\mathrm{It}$ is suspected that the independent variable has an effect on the dependent variable).

$\mathrm{Ha}: \mathrm{b} 1 \neq \mathrm{b} 2 \mathrm{~b} 3 \neq 0$ : (It is suspected that the independent variable is not dependent on the dependent variable).

$\mathrm{JKreg}=$ Sum of regression squares

$\mathrm{JKres}=$ Square residual

$\mathrm{K}=$ Number of independent variables 
$\mathrm{N}=$ Number of samples

Decision Criteria:

If FCount $>$ Ftable, then reject H0 If FCount Ftable, then accept H0

\section{Place and Time of Research}

This research was conducted at CV. Oro Kopi Gayo, Central Aceh Regency, this research was conducted in February 2016. The location determination was determined intentionally by considering that $\mathrm{CV}$. Oro Kopi Gayo is one of the industrial companies engaged in coffee processing and coffee export (coffee buying, drying and sorting coffee beans) in Central Aceh Regency, usually the coffee that will be exported with the quality provisions that have been determined, namely with the criteria of a moisture content of $14 \%$ and Trase $14 \%$ with drying workers as follows:

Table 3. Number of Workers

\begin{tabular}{|c|c|c|}
\hline No & labor & total \\
\hline 1 & 2 & 3 \\
\hline 1 & Penjemuran & 12 \\
\hline 2 & Suton & 12 \\
\hline 3 & Sortasi & 80 \\
\hline 4 & Rosting & 4 \\
\hline & Jumlah & 108 \\
\hline
\end{tabular}

Source: Data processed in 2017

From table 3 above, it can be seen that there are 12 drying workers.

Scope of Research

The scope of this research is limited to coffee drying workers at CV. Oro Kopi Gayo, Central Aceh Regency.

Sampling Method

Population

The respondents in this study were the entire coffee drying workforce at CV. Oro Kopi Gayo, Central Aceh Regency. The total population in this study were 12 drying workers.

Sample

The sample is part of the population. This means that there will be no sample if the population does not exist, to determine the number of samples as respondents in this study using the saturated sample method, meaning that all the populations used as samples are all drying workers, totaling 12 people in $\mathrm{CV}$. Oro Kopi Gayo, Central Aceh Regency

\section{Data Collection Method}

To obtain accurate and complete data so that it can support the research conducted, the following data collection techniques are used:

1. Field research, namely research conducted directly or indirectly to obtain primary data and secondary data, the methods that can be carried out are:

a. Observation

Observation is direct observation of an object to be studied. In this preparation the authors conducted observations and records systematically on the object of research, namely the CV. Oro Kopi Gayo, Central Aceh Regency.

\section{b. Interview}

Interviews are done by holding a direct question and answer session with the CV business owner. Oro Kopi Gayo, Central Aceh Regency. By interviewing, it is hoped that the actual information regarding the specifics of the data expected can complete this research.

\section{Data Analysis Method}

The method used in this study is to use simple linear regression analysis based on a functional or causal relationship, one independent variable with one dependent variable, the general equation for simple linear regression is

$\mathrm{Y}=+\mathrm{bX} 1$

Where : 
$\mathrm{Y}=$ Subject in the predicted dependent variable $=$ Price $\mathrm{Y}$ if $\mathrm{X}=0$ (constant value)

$\mathrm{B}=$ direction number or regression coefficient, which shows the increase or decrease in the dependent variable based on the independent variable. If $b(+)$ then it increases, and if (-) it decreases.

$\mathrm{X}=$ Subject on the independent variable that has a certain value.

\section{Simple Regression Analysis}

Simple Linear Regression

To find out the effect of random coffee purchases, use the following equation:

$\mathrm{Y}=+\mathrm{bX} 1$

Where :

Y: Revenue (Rp)

$\mathrm{X}$ : Number of Random Coffee Purchases (Kg) : Intersep

$\mathrm{b}$ : Regression coefficient

\section{Simultaneous Coefficient Testing (F Test)}

To test the regression coefficient simultaneously or towards the linearity of the multiple linear regression equation, the $\mathrm{F}$ test is used, with the following steps:

1. $\quad F$ Test Formula

$\mathrm{Jj}$ FHitung $=\frac{\mathrm{JK}_{\mathrm{reg}} / \mathrm{k}}{\mathrm{JK}_{\mathrm{res}} /(\mathrm{n}-\mathrm{k}-1)}$

FTabel $=\mathrm{F} \alpha / 2(\mathrm{~V} 1, \mathrm{~V} 2)$

$\mathrm{V} 1=\mathrm{k}-1$

$\mathrm{V} 2=\mathrm{n}-\mathrm{k}$

Where :

$\mathrm{JKreg}=$ Sum of squares of regression JKres $=$ Sum of squares of residual

$\mathrm{k}=$ Number of independent variables $\mathrm{n}=$ Number of samples

Decision Criteria:

If FCount $>$ Ftable, then reject H0 (the number of random coffee purchases does not affect the acceptance of drying workers at CV. Oro Kopi Gayo)

If FCount Ftable, then accept H0 (the number of random coffee purchases affects the acceptance of drying workers at CV. Oro Kopi Gayo)

\section{Partial Coefficient Test (t-test)}

The t-test was used to determine the effect of the coefficients partially/respectively. In this test, it will be known whether an independent variable $\mathrm{X}$ contributes significantly to the $\mathrm{Y}$ variable, with the following formula:

Hypothesis Formula

$\mathrm{H} 0: \mathrm{bi}=0:$ (It is suspected that the number of random purchases of coffee affects the acceptance of drying workers at CV. Oro Kopi Gayo).

Ha : bi 0 : (It is suspected that the number of random purchases of coffee does not affect the acceptance of drying workers at CV. Oro Kopi Gayo).

\section{Classical Assumption Test on multiple linear regression}

1. Normality test

2. Multicollinearity test

3. Heteroscedasticity test

\section{Operational Definitions and Limitations}

1. Sample is drying labor

2. Random coffee is coffee that CV Oro Kopi Gayo bought from farmers

3. Wages are the amount of money paid to drying workers according to the amount dried $(\mathrm{Rp} / \mathrm{Kg})$

4. The amount of drying is the amount of coffee that is dried by drying workers $(\mathrm{Kg})$

5. Revenue is the amount of drying $(\mathrm{Kg}) \mathrm{x}$ wages $(\mathrm{Rp} / \mathrm{Kg})$ 


\section{DISCUSION}

\section{Brief History of CV. Gayo Coffee}

$\mathrm{CV}$. Oro Kopi Gayo is a coffee exporter company located in the Gayo highlands in the mongal village, Bebesan District, Central Aceh Regency. CV Oro Kopi Gayo was established in October 2013. Mr. $\mathrm{H}$. Rasyid is the owner of CV. Oro Kopi Gayo who is a school teacher from the village of Mongal who has been in the coffee business for a long time.The name "Oro Kopi" comes from Italian and Indonesian. "Oro" in Italian means gold. The gold that is meant is that the coffee commodity is the gold belonging to the Gayo people. Therefore, this company is called "Oro Kopi Gayo". With a golden name, this company has become one of the companies that brought the name of Gayo coffee to all corners of the world.CV. Oro Kopi Gayo is a coffee company in the form of an individual business entity (PO) which is engaged in the processing of coffee beans (grean beans) which have been exported to several countries in the world such as the United States, Sweden, the Netherlands, Germany, Taiwan, Korea and Japan.

\section{Company Location}

CV. Oro Kopi Gayo is located on Jl. Bireun Takengon KM.100, Kampung Mongal, Kec. Bebesen, Central Aceh, Aceh, Indonesia. The location choice in this area, because it is close to farmers' plantations, making it easier for companies to enter raw materials.

\section{Drying Process in CV. Gayo Coffee}

The process of drying coffee beans in CV. Oro Kopi Gayo includes a random purchase process that is purchased from farmers in this system, usually farmers will sell coffee to collectors or collectors, then collectors will sell it to CV. Oro Kopi Gayo in the form of random coffee. After the random coffee is purchased, then the coffee is entered in the drying stage. This function is to reduce or reduce the water content of the coffee, usually the random coffee purchased has a varying water content so that it is necessary to dry it with the condition that the water content of the coffee reaches $14 \%$. Those who carry out drying activities are drying workers. Drying in carrying out its activities is usually done together, after the coffee reaches a moisture content of $14 \%$ then the coffee will enter the weighing stage to determine the number of $\mathrm{kg}$ of coffee that has finished the drying process.

Characteristics of Respondents

Characteristics of Respondents Based on Age

Age is one of the determining factors for workers in carrying out business activities, physical abilities and ways of thinking are influenced by age. Older workers tend to decrease their physical abilities and often find it difficult to accept changes or innovations because they are always based on the experiences they have experienced.

The age level of drying workers can be seen in the following table:

Table 4. Characteristics Based on Age of Respondents in Drying Labor at CV. Gayo Coffee Oro.

\begin{tabular}{cccc}
\hline No & Age group & $\begin{array}{l}\text { Total } \\
\text { sample }\end{array}$ & percentage \\
\hline 1 & $21-30$ & 4 & 33,33 \\
2 & $31-40$ & 8 & 66,67 \\
\hline & total & $\mathbf{1 2}$ & $\mathbf{1 0 0} \%$ \\
\hline
\end{tabular}

Source: Primary Data Processed in 2016

Based on table 4, it can be seen that there are 4 people in the 21-30 year age group, 8 people in the 31-40 age group with the percentage of the $21-30$ age group being $33.33 \%$ while the $31-40$ age group is $66.67 \%$. The older the drying workforce, the less ability to do work, so that it will reduce their work productivity.

Characteristics of Respondents Based on Education

Education in this study is measured based on the level of formal education that has been followed. The characteristics of drying workers can be seen in the following table:

Table 5. Characteristics Based on Education of Respondents Drying Labor in CV. Gayo Coffee Oro.

\begin{tabular}{cccc}
\hline No & $\begin{array}{c}\text { Education } \\
\text { group }\end{array}$ & $\begin{array}{c}\text { Total } \\
\text { sample }\end{array}$ & percentage \\
\hline 1 & $0-9$ & 3 & 25 \\
2 & 12 & 9 & 75 \\
\hline
\end{tabular}




\section{Source: Primary Data Processed in 2016}

total

12

$100 \%$

Based on table 5, it can be seen that the education level of 0-9 years is 3 people, education 12 is 9 people with the percentage of $0-9$ years education level is $25 \%$ while the level of education 12 is $75 \%$. From an education perspective to become a drying worker does not affect the results of the drying process. themselves because to become a drying worker is not determined through the level of education.

Characteristics of Respondents Based on Number of Dependents

The number of dependents illustrates that the greater the costs incurred to cover the necessities of life, the more the number of dependents, the more costs must be incurred to meet the necessities of life.

The characteristics of the number of dependents on the drying workforce can be seen in the following table:

Table 6. Characteristics Based on the Number of Dependents of Respondents

Drying Labor in CV. Gayo Coffee Oro.

\begin{tabular}{cccc}
\hline No & $\begin{array}{c}\text { the number of } \\
\text { dependents }\end{array}$ & $\begin{array}{c}\text { Total } \\
\text { sample }\end{array}$ & percentage \\
\hline 1 & $0-3$ & 11 & 91,67 \\
2 & $4-6$ & 1 & 8,33 \\
\hline & total & $\mathbf{1 2}$ & $\mathbf{1 0 0} \%$
\end{tabular}

\section{Source: Primary Data Processed in 2016}

Based on table 6 , it can be seen that the number of dependents $0-3$ is 11 people, while the number of dependents 4-6 is 1 person with the percentage of dependents $0-3$ is $91.67 \%$ while the number of dependents 4-6 is $8.33 \%$. The number of dependents is the number of dependents of the drying worker itself, the more the number of dependents, the greater the needs that must be met by the drying workers themselves.

Characteristics of Respondents Based on Length of Work

Work experience is one of the supporting business activities, the longer they work, the more experience they will get from where they work.

The characteristics of the experience of drying workers can be seen in the following table:

Table 7. Characteristics Based on Length of Work Respondents Drying Labor at CV. Gayo Coffee Oro.

\begin{tabular}{cccc} 
No & $\begin{array}{c}\text { length of } \\
\text { work (year) }\end{array}$ & $\begin{array}{c}\text { Total } \\
\text { sample }\end{array}$ & precentage \\
\hline 1 & $0-10$ & 7 & 58,33 \\
2 & $11-20$ & 5 & 41,67 \\
\hline & total & $\mathbf{1 2}$ & $\mathbf{1 0 0 \%}$
\end{tabular}

Source: Primary Data Processed in 2016

Based on table 8 , it can be seen that the length of work $0-10$ years is 7 people, while the length of work for 11-20 years is 5 people with the percentage of working $0-10$ years is $58.33 \%$ while the length of work for $11-20$ years is $41.67 \%$. If seen from the explanation above, it can be concluded that the higher the level of length of work or work experience, the more mature a drying worker will be because the more knowledge and drying systems are good and thorough and able to provide lessons to those who are new.

Drying

The drying process is carried out at CV. Oro Kopi Gayo is the result of buying coffee at random with the criteria of varying moisture content and then drying it with a predetermined moisture content of $14 \%$. Before the coffee is dried in the sun, the coffee will be weighed first to determine the number of kilo grams of coffee to be dried.

The number of original coffee purchases can be seen in the following table:

Table 8. Average Number of Random Coffee Purchases in CV. Gayo Coffee Oro.

\begin{tabular}{rrr}
\hline No & month & total(Kg) \\
\hline & & \\
1 & January - December 2016 & 289.552 \\
\hline & total & 289.552
\end{tabular}

Source: Primary Data Processed in 2016 
Based on table 8 , it can be seen that the average number of random coffee purchases from January to December 2016 was $289,552 \mathrm{Kg} /$ Year.

Table 9. Average Acceptance of Drying Workers in CV. Gayo Coffee Oro.

\begin{tabular}{ccc}
\hline No & month & total (Rp) \\
\hline & January & - December 2016 \\
total & 33.684 .094 \\
\hline & & 33.684 .094 \\
\hline
\end{tabular}

Simple Linear Regression Test

A simple linear regression test was carried out to determine the effect of the independent variable in this case the number of original coffee purchases on the dependent variable in this case the reception of drying workers at CV. Oro Kopi Gayo, Central Aceh Regency.

Normality Test

From the results of the normality test regression can be seen in the following figure:

Table 10. Regression Results Using Multicollinearity Test

\begin{tabular}{llcc}
\hline Model & & \multicolumn{2}{c}{ Correlations } \\
\cline { 3 - 4 } & & Tolerance & VIF \\
\hline 1 & $\begin{array}{l}\text { (Constant) } \\
\text { original purchase amount }\end{array}$ &, 851 &, 851
\end{tabular}

Source: Processed Primary Data in 2016.

From table 10 above, it can be seen that all variables value $\mathrm{VIF}<10$ and the value of tolerance $>0.8$. This shows that the existence of multicollinearity in the equations carried out is not proven. In other words, there is no multicollinearity in the equations carried out or the relationship that occurs between the independent variables can be tolerated so that it will not interfere with the regression results.

Conformity Test Test Of Goodness Of Fit

The analysis of simple linear regression analysis from the results of data processing that has been carried out previously is as follows: $\mathrm{Y}=9.351+0.085 \mathrm{X} 1$

From the simple linear regression equation model above, the constant value listed is 9.351 meaning that the value of $\mathrm{Y}$, namely acceptance, is 9.351 . The regression coefficient of the $\mathrm{X}$ variable, namely the number of random coffee purchases is 0.085 , which means if the value of the independent variable continues to increase by $1 \%$. Then the result of the independent variable value is 0.085 . The regression coefficient of the independent variable is 0.000 , which means that the value of the independent variable continues to increase by $1 \%$, so the revenue result will increase by 0.000 .

\section{CONCLUTION}

Based on the results of research and discussion, it can be concluded that

1. Based on the results of the partial analysis, the value of t Count $=5.121>$ ttable 2,228 the higher the number of purchases of coffee without eating, the higher the reception of drying workers.

2. Analysis of simple linear regression analysis from the results of data processing that has been carried out previously is as follows: $\mathrm{Y}=9.351+0.085 \mathrm{X} 1$

From the simple linear regression equation model above, the constant value listed is 9.351 meaning the value of $\mathrm{Y}$, namely acceptance, is 9.351 . The regression coefficient of the $\mathrm{X}$ variable, namely the number of random coffee purchases is 0.085 , meaning that if the independent variable the value continues to increase by $1 \%$. Then the result of the independent variable value is 0.085 . The regression coefficient of the independent variable is 0.000 , which means that the value of the independent variable continues to increase by $1 \%$, so the revenue result will increase by 0.000 . 


\section{REFERENCES}

[1] Affif, Faisal, (2012), "Blue Ocean Strategy dan Ekonomi Kreatif”, Rangkaian Kolom Kluster I, Jakarta: Binus University.

[2] Basri,S.(2011), Uji Regresi Berganda. April 2011 http;//setebasri01. blogspot, co.id/2011/uji-regresiberganda.html

[3] Direktorat Jenderal Perkebunan. 2013. Produksi Kopi Menurut Provinsi di Indonesia, 2008 - 2012.

Departemen Pertanian.

[4] Dumairy.1997.Perekonomian Indonesia.Jakarta:Erlangga

[5] Haryanto,B. 2012. Prospek Tinggi Bertanam Kopi. Pustaka Baru Press, Yogyakarta.

[6] Irawan. N. Dan S . D. Astuti. 2006. Mengolah Data Statistik dengan metode menggunakan minitab. 14. Penerbit Andi. Yogyakarta

[7] M. Iqbal Hasan, Pokok-pokok Materi Statistik 1. Di terbitkan oleh PT. Bumi Aksara, Jakarta 2002.

[8] Mulato, S. 1994. Praktek pengolahan Kopi. Bahan Kusus Pengolahan Kopi dan uji Cita Rasa. Pusat Penelitian Kopi dan Kakao.

[9] Oscar Yulius, SPSS 18, Tim Panser Pustaka 2010.

[10] Ridwansyah. 2003. Pengolahan Kopi. http://www.library.usu.ac.id/download/fp / tekper-ridwansyah4.pdf. [16November-2009]

[11] Simanjuntak, Payaman J. 2005. Manajemen dan Evaluasi Kerja. Lembaga Penerbit FE-UI, Jakarta.

[12] Soekartawi, 1995). Analisis Usahatani. Universitas Indonesia (UI-Press) Jakarta. Soekartawi, 2005). Teori Ekonomi Produksi. Raja Grafindo Persada. Jakarta.

[13] Usman Rianse (2008). Pengantar Statistik. PT. Bumi Aksara, Jakarta.

[14] Winarni dan Sugiarso, Administrasi Gaji dan Upah, Yogykarta: Pustaka Widyatama, 2006, h.10-12.

[15] Wahyuni, E., Karim, A dan Anhar, A. 2013. Analisis Citarasa Kopi Arabika Organik Pada Beberapa Ketinggian Tempat Dan Cara Pengolahannya Di Datararan Tinggi Gayo. Jurnal Manajemen Sumberdaya Lahan. Volume 2, Nomor 3, Juni 2013: hal. 261-269.

[16] Penelitian yang dilakukan oleh Asri Yarsi (2006) yang berjudul “Analisis Pendapatan dan Penyerapan Tenaga Kerja pada Sistem Kemitraan Usaha Perkebunan Kelapa Sawit (Kasus Pola Kemitraan di PT. Perkebunan Nusantara VI dan PT. Bakrie Pasaman Plantation, Kabupaten Pasaman Barat Provinsi Sumatera Barat)"

[17] Penelitian yang dilakukan oleh Desi Nurhayati (2016) penelitan yang berjudul "Analisis Pendapatan Tenaga Kerja Wanita Pada Perkebunan Teh Ptpn Iv Kebun Bah Butong Kecamatan Sidamanik".

[18] (https://id.wikipedia.org/wiki/Tenaga_kerja) (http://kopinian.blogspot.co.id/2016/04/cara-pengeringan-bijikopi-yang-aik.html) 